\title{
Kinship and Territorial Ties within the Power System of the Traditional Kabardian Society
}

\section{Yuzanna Azikova}

Kabardino-Balkarian State University named after H. M. Berbekov, Nalchik; Federal State Budgetary Scientific Establishment 'Federal Scientific Center Kabardin-Balkar Scientific Center of the Russian Academy of Sciences', Nalchik

\begin{abstract}
The purpose of the present article is to outline the role of kinship and territorial ties in the power system of traditional Kabardian society. In connection with the discussions on the issue of the emergence of the state, which is mainly based on territorial division, the article analyzes the nature and level of the kinship and territorial ties existing in traditional Kabardian society. It is shown that between the sixteenth and eighteenth centuries the true kinship between the rulers and the governed was completely excluded in Kabardia; however, the practice of imitation of kinship was typical since the ruling upper circles were aware of high functionality and efficiency of tradition and ideology of kinship in ruling the people and the country. The article also analyzes the presence of the elements of kinship and their alternatives in the history of relations between traditional Kabardian society and 'foreign-language periphery,' neighboring peoples and states (in the period from the sixteenth to eighteenth centuries). The author also evaluates the pragmatic or ideological significance of kinship rhetoric and contacts for the historic reality of international relations in the region.
\end{abstract}

Keywords: traditional Kabardian society, power system, prince power, international relations, kinship, artificial kinship, consanguinity, territorial ties, territorial division, early state.

Social Evolution \& History, Vol. 20 No. 1, March 2021 114-145

(C) 2021 'Uchitel' Publishing House

DOI: $10.30884 / \mathrm{seh} / 2021.01 .05$ 
THE PROBLEM OF THE DYNAMICS OF KINSHIP AND TERRITORIAL TIES WITHIN POLITICAL GENESIS

According to the point of view dominating among modern political anthropologists, the state is not just a set of political institutions but a type of society which this set of institutions corresponds to (Bondarenko 2008: 19). The societal type is determined by the nature of the ties and relations dominant in the system under consideration. The idea common for almost all schools and theories of political genesis is that the emergence of a state is associated with the transition from tribal to territorial principle of societal organization (Grinin and Korotayev 2012). For a long time, researchers opposed the kinship-based prestate society to a state society based on territoriality and they also linked the eventual formation of the state with a complete replacement of kinship ties by territorial ones (Bondarenko 2008: 19-20; Engels 1986). Subsequently, the obsolescence of such views on the problem became apparent. Ethnographers and historians (especially the medievalists) have shown that typologically the non- and initially pre-state institutions of kinship can and do remain important in state societies (Kubbel 1988: 117-118; Bondarenko 2008: 20).

At present, the researchers reject an over-simplified opposition between kinship and territoriality, though the historical trend of gradual replacement of the institutes relying on kinship by those based on territorial division is hardly denied (Bondarenko 2005; Chabal, Feinman, and Skalník 2004; Bondarenko, Grinin, and Korotayev 2002; Grinin 2003). Nevertheless, the problem of a lower limit of societal complexity of the state in general, and of the early state in particular, remains unresolved and debatable (Claessen 2012, 2016) since different researchers have varying views on the acceptable degree of available family relations and on the essential level of territorial ties for the state formation.

The creators of the early state concept, Henri J. M. Claessen and Petr Skalník (Claessen 2002, 2005; 2008: 13) also developed a typology of early states based on the degree of maturity and respectively identified inchoate, typical and transitional states. According to them, the inchoate early state is characterized by domination of clan ties; the typical early state - by the preservation of clan-lineage ties together with some development of relations beyond clan in the operating subsystem; and the transitional early state is characterized by the prevailing appointments to positions in the administrative apparatus while kinship ties preserve their role only at the highest levels of hierarchy (Kradin 2006: 187-188). 
According to Leonid S. Vasilyev, the early state based on clan and supra-clan ties exercises a centralized control over a large territorial and administrative complex and ensures prestigious consumption (Vasilyev 1983).

According to Leonid E. Grinin's definition, the early state is built '(basically or mostly) not on the principle of kinship' (Grinin 2006: 86-87). One should emphasize that a vast majority of researchers distinguish the replacement of patrimonial division of society by territorial one, the introduction of taxes and emergence of the special power separated from people in the form of administrative and repressive apparatus as the most important characteristics of statehood. Thus, Grinin considers it necessary 'to reject the application of the triad to the early states, using it for characteristic of the developed states only' (Grinin 2007: 30-35).

Dmitri M. Bondarenko takes an intermediate position between Maine-Morgan-Engels approach (arguing that in social and political terms the state in its full sense emerges when territorial division almost completely forces out the patrimonial division) and the approach of developers of the early state concept (proponing the idea that initial, but still a state can be somehow connected with domination of kinship, family and communal ties in the political field). He notes that 'the state in its full sense may be established in the situation when territorial ties clearly (though not overwhelmingly) dominate over those of kinship at the supralocal levels of societal complexity' (Bondarenko 2008: 23).

In the national Kabardian studies (of the pre-revolutionary, Soviet and modern periods), the problem of a proper degree of available kinship ties and essential level of territorial ties for the formation of the Kabardian state during the traditional period has never been definned and resolved. The debates arose around the existence, functioning and domination of 'patriarchal and patrimonial vestiges' on the one hand, and of 'feudal relations,' on the other. The works of pre-revolutionary authors like Stepan Burnashev, Petr A. Gavrilov, Nikolay Dubrovin, Fedor I. Leontovich, Jacob V. Abramov, Michael I. Kulisher, Evgeniy Maximov, Gregory Vertepov and others described the domination of patriarchal and patrimonial mode of life when assessing social and economic system of the Kabardian and other Caucasian communities. On the other hand, such authors as Semyon Bronevsky, Karl Stal, Maksim Kovalevski, Shora Nogmov, Vladimir Kudashev and others recognized the existence of a feudal system in Kabardia (Naloeva 1972: 69-70). When considering this problem, the Kabardian studies of the Soviet period, as well as the subsequent historical thought re- 
stricted to the assumption about 'a close intertwining of the feudal relations with patriarchal and kindred ones with an obvious domination of the former' (or to ideas about 'preservation of certain elements of the earlier formation within the frames of the new one; or disguising of development of the feudal relations by patrimonial ties' and others) (Kokiev 2005: 19-23, 434-441; Kumykov 1954: 68; Kusheva 1956: 97-121; 1963: 108; Gardanov 1967: 243, 321, 329; Naloeva 1968: 68; 1980: 5-27).

Against this background of the 'kinship/territoriality' model of public relations an innovative approach to the problem was developed by Valery Kh. Kazharov. In the study of the Adyghe rural community, he showed that poorly studied and 'non-standard' peculiar features of the Adyghes' social order should be considered as integral components of the Adyghe feudal society which are closely connected with its entire social and economic structure (Kazharov 1982: 7-8; 1992: 8-10) but not as notorious vestiges which may be interpreted as annoying misunderstanding that spoils a harmonious picture of the postulated explanatory schemes developed on the European material.

\section{KINSHIP VALUE FOR THE TRADITIONAL KABARDIAN SOCIETY}

Marc Bloch wrote that

The ancient, kindred relations created in a bosom of patrimonial society, alien, in essence, to relations between people of new feudal structure, played a role in it still so considerable that it is impossible to exclude them from an overall picture ... According to chroniclers, a basis of power of barons, be they from Normandy or Flanders, were not only their castles, hard coin income, numerous vassals, but also their kin. At any step of a social ladder, including the lowermost, kinship was appreciated (Bloch 2003: 125-126).

The kinship value for traditional Kabardian society was similar to the situation described by Marc Bloch. Moreover, some researchers' idea about the dominating patriarchal-clan structure in traditional Kabardia (or Kabarda) was the result of theorizing based on the study of evident data. For example, Ivan F. Blaramberg wrote, 'The relationships existing in the Circassian society are as follows: 1) the ties resulting from the admission of children for upbringing; 2) kinship through adoption of children; 3) the bond based on the brotherhood oath; 4) marriage bonds; and 5) trade relations' (Blaramberg 1974: 396). It is obvious that Blaramberg hardly mentioned all relations ex- 
isting in the Adyghe society; but the fact that from the whole range of relations he distinguished just those (four out of five) that were related to the category of 'kinship', is significant.

It is also noteworthy that in the Adyghe language in general and in the Kabardian language in particular, there exists an extended and developed kinship vocabulary indicating an exceptional development and rootedness of this connecting segment of society.

The traditional Kabardian society was familiar with all types of kinship: by blood, by marriage (connection by marriage) and by declaring relatives (artificial, or named kinship). Kinship by blood would unit such units as family, ${ }^{1}$ parentage (lineage, patrilineage, patronymy - wunakuosh) (Kosven 1961: 116, 32-41; Pershits 1951; Studenetskaya 1950; Gardanov 1967: 138-139; Musukaev, Pershits 1992: 13-87), kin (clan - l'epk, l'akua) (Bgazhnokov, Berzegova 2005: 332-333).

To be a part of Kabardian society meant, first of all, to be a part of a community connected by kinship. A Kabardian was born and immediately became a member of a group united by some kind of kinship. He justified his estate rights and obligations by affiliation (and duration of this affiliation) to one or another kindred group. In the Kabardian society of the traditional period, the deprivation of 'citizenship' was, first of all, the exclusion from the circle of relatives, deprivation of patronage, help and protection of this circle with all the ensuing consequences (Archive IHS KBSC RAS. Fund 1. Inventory 1. Case 2. P. 220-228; Karlgof 2004: 110-116). A similar situation was observed at all levels of the social ladder.

\section{KINSHIP IN THE RELATIONSHIP SYSTEM \\ OF THE KABARDIAN PRINCES}

The history of the princely family is quite well known to researchers due to its relatively wide descriptions in different sources. The very fact of its existence is a kind of indicator illustrating the enormous role of the kinship category and parentage ties in the life of traditional Kabardian society.

According to the legend, ${ }^{2}$ in the princely Kabardia all ruling dynasties traced their descent to a common ancestor; so the princely caste was presented as a single clan within which the branches of the dynasty were singled out. It was legendary Inal who was considered the common ancestor of this clan (Siver 2007: 43). In traditional Kabardia, similar to the Franks' early feudal state, there was observed a mandatory participation of all living brothers in governing the country (corpus fratrum). This phenomenon may be associated with the original idea of the sacred nature of power, the latter regarded as the 
property of the ruling family to which the common inheritance law was extended (Nazarenko 1986: 150-151).

As is known, the genealogical legends performed an important function among oral societies. With their help, people identified their place in a group. The Kabardian princes were no exception to the rule. They were obliged to know their genealogy (at least, down to the seventh generation) not for the sake of history (although this is also important) but because of dire necessity. Like Óttarr from Hyndluljó who needed to know his pedigree to prove his right to father's inheritance (Gurevich 1977), the Kabardian princes also had to know their family tree in order to fully exercise the rights and duties provided by the princely family status.

In Kabardia the princely family was welded not only by the hereditary right to exercise power functions (the suzerainty of Inal's descendants over Kabardia) but also by economic solidarity. The Kabardian lands were in the supreme ownership of the princely family (OCSA AS KBR. Fund P-1209. Inventory 13. Case 28. P. 52-55; Novitsky, Mogukorov N.d.: 2) so peoples would pay tribute to the princely family's representatives for generations (Archive IHS KBSC RAS. Fund 1. Inventory 1. Case 14 a. P. 210) and also the princely treasury was replenished via trade duties from the merchants crossing Kabardia (OCSA AS KBR. Fund P-1209. Inventory 18. Case 17. P. 34; OCSA AS KBR. F. P-1209. In. 8. C. 2. P. 1; OCSA AS KBR. F. P-1209. In. 8. C. 25. P. 14-15).

The princely solidarity was also strengthened by the constant military threat both from inside and outside Kabardia. In times of civil infightings or external danger, the number of brother-princes became of immense importance. In case of any internal clashes (assuming that no external forces fought on the side of the belligerents), theoretically the side that had more princes had more chances to win: first, more princes could engage more vassals; secondly, more princes - more people inviolable for the worqs of the opposing side (worqs, having no right to fully defend themselves, could die by a hostile but still inviolable prince's hand). In case of external forces, this rule also worked: more princes meant more worqs and more professional soldiers. Petr G. Butkov noted that 'when the owners of Major Kabardia noticed that the owners of the Minor Kabardia were weakening and the clans of the latter became smaller in numbers (italics added. $-Y u$. A.), the former started to make claims under the law of the strongest ...' (Butkov 2001: 153). Frederic Dubois de Monpere and Tebuu de Marigny also noted that the power of the princes directly correlated with the number of vassals, allies, and relatives (Marigny 1974: 297; Monpere 1974: 437). 
Despite the fact that for oral societies the events of the recent past acquire a trace of antiquity verging on myth, for the Kabardian princes the presence of a single ancestor, Inal, was real and that allowed them to call each other 'brothers'. The genealogies available to the researchers also evidence the consanguinity among the Kabardian princes (Demidova, Kusheva, and Persov 1957: 383-387). The Minor-Kabardian princes, though complaining about the oppression on the side of the princes of Major Kabarda ${ }^{3}$ and in every way denying the unity of the territory they ruled, would still call them brothers (Bukalova 1957: 200). The prince of the Kashkatau party, Janbulat Kaitukin, called the princes of the Baksan party not only adversaries but also brothers (OCSA AS KBR. F. P-1209. In. 8. Case 1. P. 156). Princes from Kabardia during the strife were driven out by the brothers and vice versa (Archive IHS KBSC RAS. F. 1. Inv. 1. Case 14 a. P. 77; OCSA AS KBR. F. P-1209. Inv. 18. Case 18. P. 155). The disgrace of this or that prince was accompanied by his 'exclusion from the list' of brothers (OCSA AS KBR. F. P-1209. Inv. 18. Case 14. P. 161). According to Ekaterina N. Kusheva (1956: 119), the 'patriarchal' custom of choosing the elder grand prince for whole Kabardia was preserved up to the destruction of the political system of the traditional Kabardia and serves a vivid illustration to what extent the Kabardian princes were aware of their kinship.

The blood-related cohesion and solidarity of the princely family, described above with the help of data presented in the sources, can be easily broken with the help of other evidence. In the case of the princely family of traditional Kabardia, the concept of 'family' is associated primarily with such realms as tradition and ideology and does not reflect the real patriarchal nature of relations in the princely caste. As was mentioned above, the consanguinity of the Kabardian princes is a reality, not a myth, and first of all, for the princes themselves. But in terms of the implementation of the subject/object model of power, this is no longer just a given fact, but a guide to action in streamlining the exercise of monarchial power in Kabardia. This is not a relationship determined exclusively by the ideology of kinship but by the ideology of power.

In connection with the above-mentioned, it is necessary to consider the issue of princely internecine strife in general and clashes motivated by blood feud, in particular. The ideology of kinship did not encourage internecine strife between brothers. But the Kabardian princes were not guided by this canon until it served their interests. The sources on princely coexistence in Kabardia present numerous records of permanent confrontation among Kabardian pshi (princes). 
Here we have a typical situation of significant discrepancies between normative ideology and reality ('society is forced to provide leaders with power that could allow them break and cancel the rule itself' [Bondarenko, Nemirovskiy 2009]). In terms of implementation of the subject/object model of power relations that is a pseudo-contradiction. Similar to other communities, in traditional Kabardia there were no valid reasons to condemn internecine strife when it was aimed at defense and exercise of legal rights; while in other cases it was condemned (Korolenkov 2009). However, during the clashes between brother-princes, each of the opposing sides could present convincing arguments in defense of their aggressive actions.

The issue of blood feud remains critical. For the whole Kabardian society, there was a rule that cultivated kinship solidarity, condescension to the mistakes of the relatives and their forgiveness. The reconciliation of blood feud between the non-relatives could be promoted by the establishment of an artificial kinship between them (Grabovsky 1870: 32; The Legend of the Eshanokov brothers... 1891). The Kabardian princes had no necessity to establish a kinship with each other since it already existed but did not prevent murder and blood feud among them. Aleguko Shogenukov and his relatives commented on this issue, 'we have a custom from our fathers and grandfathers, that we, Circassians, kill each other to death if offended' (Archive IHS KBSC RAS. F. 1. Inv. 1. Case 11. P. 387).

Karl Koch wrote, '... marriages between relatives are not common among the Circassians. A young man is not even allowed to marry a girl from the same clan, since all members of this clan are considered relatives' (Koch 1992: 61). Exogamy was also extended to people included in the kinship through atalykism, adoption, etc. The members of Kabardian princely families married representatives of elites from beyond.

The most important attributes of the patriarchal way of life 'blind obedience to parents and deep respect for elders' (Blaramberg 1974: 378) firmly rooted in the minds of Kabardians but did not always correspond to the realities of princely coexistence. At first, this was facilitated by atalykism which established kinship in the vertical dimension, but weakened the kinship feelings in the horizontal one. Pallas wrote on this subject, "the upbringing of the princely children of this nation is aimed at destroying every kindred feeling from an early age' (Pallas 1974: 222). Jan Potocki noted, 'every prince is so independent that they do not even have the custom that sons submit to their parents' (Potocki 1974: 227). No one dared to repeal this 'custom' for princes but one can easily notice the divergence between normative ideology and reality: the declared unquestioned obedience 
of youngsters to the elders did not always work in the princely surroundings (Delpozzo 1808: 30; Archive IHS KBSC RAS. F. 1. Inv. 1. Case 14a. P. 34; OCSA AS KBR. F. P-1209. Inv. 8. Case 1. P. 99) where everyone was a part of the ruling clan and clearly realized it.

\section{ESTABLISHMENT OF AN ARTIFICIAL KINSHIP IN A SITUATION OF UNACCEPTABLE REAL RELATIONSHIP}

The category of kinship and kinship relations played an important role in the interrelationship between subjects and objects of power. In the adats one could observe various signs of respect and reverence that should be displayed towards the prince. However, similar signs were also manifested towards the 'elders' (nakhizh) from groups of relatives of different levels. The prince was 'helped as a relative' to receive his guests, pay his debts, pay his dues for the bride, build a new house (OCSA AS KBR. F. P-1209. Inv. 11. Case 25. P. 17-18 turn.; Pershits 1951: 179). The most important duty and right of a certain circle of relatives - the blood feud for shedding noble blood - was carried out by princes (OCSA AS KBR. F. P-1209. Inv. 18. Case 14. P. 58). As noted in one of the sources, 'in the case of someone killing a pshikeu the blood revenge as if for his own relative (italics added $Y u . A$.) was executed by the prince in whose service was the killed noble, and most of the blood payment went to the benefit of the revenging prince' (Note on Privileged Estates... 1997).

The artificial kinship relations between subject and object of power were established in a deeply stratified society imbued with ideology and practice of suzerain-vassal relations. The blood feud 'could not be turned against a person standing higher up in the feudal hierarchy.' It usually acted from the top down in relation to persons of lower rank and horizontally between members of the same social group (Sherieva 2005).

The 'Explanatory note' presented by the estate-land commission cites an interesting passage state that,

a curious habit existed in the North Caucasus: when a son was born to a prince, a child was taken from village to village and the women of those villages alternately breast-fed the child; this habit established close ties of brotherhood between princes and their subordinates and connected them with kinship bonds (Archive IHS KBSC RAS. F. 1. Inv. 1. Case 23. P. 13 turn.).

This passage illustrates the way the artificial relationship could be established between subjects and objects of power. 
When describing the layout of the princely aul (village, settlement), where various categories of peasants and noblemen lived, it is noted that 'these people organize the princely house according to the folk custom because decency required that the princely kunak room (guest room) should never be empty' (Archive IHS KBSC RAS. F. 1. Inv. 1. Case 23. P. 14 turn. - 15). In other words, the nobles and peasants were directly connected with the prince's house, with his family and kindred circle. Such relationships presupposed, first and foremost, close personal ties and only then some other. The names of princely auls where the prince's subjects (i.e., nobles and peasants) lived, had a patronymic origin - the ownership suffix was added to the generic name of the owner (-ey) and thus formed the name of the village (Kazharov 1992: 15). The subjects of the Kabardian princes were ruled not by single prince, but by princely families (Klaproth 1974: 260). Their submission to a certain princely family was not individual but together with the family. This partly contributed to preserving 'settlement by clans' (Studenetskaya 1954: 157) or 'the patronymic principle of settlement' (Musukaev, Pershits 1992: 58). Foreigners who immigrated to Kabardia for some reason, entrusted themselves to the patronage of one of the princely families, 'after which all their descendants were considered as belonging to the family which the first immigrant had joined' (OCSA AS KBR. F. P-1209. Inv. 11. Case 24. P. 10).

With the whole range of possible ways of establishing artificial kinship in traditional Kabardian society (adoption, fraternity, and atalykism [Musukaev, Pershits 1992: 123]) it is worth paying special attention to atalykism. Mark O. Kosven noted that, 'in archaic terms the atalyk is the maternal uncle of a fostered child' (Kosven 1961: 124). Thus, atalykism, having rather ancient origins, existed in the considered region and time period in a somewhat transformed form. It surpassed the family frames and penetrated into the system of subject/object power relations. While the presence of atalykism could be fixed within the horizontal ties, still it was mostly applied within the vertical dimension of the traditional Kabardian society.

In the Russian sources atalykism was first mentioned in the 'Description of the Kabardian People' (1748), compiled by the councilor of the Collegium of Foreign Affairs Vasily M. Bakunin who stated that

every ruler could neither have his children with him nor see them with his own eyes until his very old age, and for that reason the ruler's newborn son was immediately sent to his uncle, one of the nearby uzdens, who would find a nurse for him; and when the boy reaches a proper age the atalyk 
would teach him the archery art and firearms and fencing with sables to cut and stab and other military exercises according to their custom (Kosven 1961: 104).

Analyzing this passage, one should note that: 1) the text immediately brings about the idea that atalykism was not spread throughout the traditional Kabardian society, but at the highest level of its power hierarchy; 2) only a person who is socially inferior but still well-born could become an atalyk for a princely son; and, finally, 3) the mentioned military education and not any other kind, is an additional confirmation that the execution of the custom of atalykism was not only a right but also an obligation of the nobility caste.

Khan-Girey pointed out that

from olden times the princes have sought to increase their strength through searching for all possible means to attach the nobles, while the latter wanted to get closer to the princes for the sake of constant protection and help when needed. The poorest always and everywhere need the help of the richest, and the weakest need the patronage of the strongest. For such a mutual rapprochement, the most effective way was found in the custom of raising children which, connecting the two families in a certain sense by blood kinship, brought ... mutual benefits and, as a consequence, gave rise to this strange and harmful for folk morality habit, accepted by the force of the law, sanctified by time and supported by deep-rooted people's belief, that the prince, whose children were brought up in his own house, is weak in spirit, and such an opinion would damage his power, and, moreover, he would be considered a miser, which the Circassians considered to be a greatest shame. In order to avoid such an opinion, both princes and high noblemen adhere to this ritual, the reason for the introduction of which seems to be explained in this way (Khan-Girey 2008: 310-311).

Khan-Girey proves the strange and harmful character of this custom by the fact that brother-princes, brought up by different atalyks, love the atalyk's family more than their own, which gives rise to fratricide and disobedience towards their native father-prince (KhanGirey 2008: 310).

Thus, atalykism established sacred ties between the kinship circle of the fosterling and the kinship circle of the caregiver. This relationship implied obligations no less than blood relations and sometimes even more. Without giving details of the ceasefire between the Baksan 
and Kashkatau parties in November $1754,{ }^{5}$ we can cite several passages from the 'Records of events that occurred around the Kizlyar Fortress ...' (the journal of Petr Tatarov and Ivan Barkovsky). It is noted that after the Kashkataus and the Baksans had sworn on the Qur'an, Hammurza Raslanbekov took the oath separately. The Kashkatau party refused to treat Hammurza as a brother and, accordingly, to take an oath with him because of his self-will and failure to comply with the demands of other princes of this party. The princes from Hammurza's family, Beslan Hammurzin, Kaituka Kaisimov, worq Batyr Kudenetev and a few other worqs would also swear separately (OCSA AS KBR. F. P-1209. Inv. 18. Case 15. P. 163-167). The described situation is really curious: Kaituka, theoretically being part of the Kashkatau party, swears together with the outsider Hammurza only because Kaituka's atalyk 'is in the same oath with Hammurza,' in other words, for Kaituka his atalyk's union with other prince is of primary value while the fact of that prince's disgrace is of secondary importance. The most interesting thing is that other princes, although being angry with Hammurza, do not oppose Kaituka in his actions (at least this is not mentioned in the source). Moreover, such actions are justified by the words 'according to their customs.'

The establishment of kinship between a prince and a noble worq through atalykism was a way to make a new subject fall under the prince power. This aspect was quite clearly recognized by the participants of such events. That is, the dispute eventually concerned the subject/object power relations although it all would start from a seemingly trivial establishment of artificial kinship without a stated political motive. For example, Petr Tatarov and Ivan Barkovsky more than once had to listen to the complaints of the Minor Kabardian princes, who claimed that the Anzorovs (first order nobles), for example, were subjects of the Tausultan princes since ancient times. However, the princes of Major Kabardia lured them to themselves making them their children's atalyks. That was in this way that the Minor Kabardian noblemen Anzorovs, Murtazins and Kogolkins fell under the power of the princes of Major Kabardia (OCSA AS KBR. F. P-1209. Inv. 8. Case 2. P. 179). Blaramberg also notes that, 'the princes of Major Kabardia willingly give their sons to be brought up by the nobles of Minor Kabardia in order to establish ties with them and thereby get an opportunity to weaken the power of the Minor Kabardian princes' (Blaramberg 1974: 380).

Those who managed to become the princely atalyks (so it is no wonder that many would compete for this privilege) (Stal 2001: 232; Koch 1992: 50) and to affiliate with the princely family, became ex- 
tremely influential. Thus, in captain Shakhovsky's 'Note ...' it is said that an atalyk 'enjoys his [prince's] respect; the prince consults with him on many matters so the atalyk solves the problems even without the prince's permission. And when the prince dies, the atalyk cuts off half of his ear as a sign of mourning and his whole family mourns with him' (OCSA AS KBR. F. P-1209. Inv. 2. Case 22. P. 28). The 'quarrel' between Biksha (the atalyk of Prince Sholokh Sunchaleyevich [Archive IHS KBSC RAS. F. 1. Inv. 1. Case 11. P. 341342]) and Prince Kelmamet Kudenetovich is significant in itself. In 1634, Kelmamet Kudenetovich complains to Tsar Mikhail Fedorovich and seeks for his protection. According to him, Biksha, the atalyk of Prince Sholokh, invited Prince Kelmamet Kudenetovich to visit him. Prince Ildar Ibakov and the noble kodz Inaluka Khotov were also present. A quarrel broke out between Kelmamet and Biksha and apparently Biksha told Prince Kelmamet, 'if you hit me, I will cut off your head.' Kelmamet becomes indignant; he writes that it is not customary for them that a nobleman dares to threaten the prince, especially in public. Then Kelmamet says that he did not dare to respond to Biksha because he was in the sovereign's town of Terek. At the same time, the prince adds that Biksha insulted him intentionally with the connivance of Prince Sholokh Sunchaleyevich Cherkassky (Archive IHS KBSC RAS. F. 1. Inv. 1. Case 8. P. 221). Noteworthy is the order of words uttered by Biksha and quoted by Kelmamet, 'If you hit me, I will cut off your head.' Kelmamet inadvertently made it clear that he had intended to hit Biksha. In Biksha's quoted words, in addition to the insult, Kelmamet's statements appear as well, which led to Biksha's retorted abuse. But why does he appeal to the Tsar, and not to other princes as well as to the rights and customs that protect princes' dignity? Perhaps, the matter is that in this episode Kelmamet himself appeared a violator of customary law suggesting the possibility of hitting the atalyk of Kabardian prince of not lower rank. In addition, it is not Biksha who went too far in his threats relying on his relative, but Kelmamet who relied on the patronage of the Russian Tsar. The cited source illustrates the indisputable privileges of an atalyk.

There was observed an ambiguous situation in traditional Kabardian society: on the one hand, the kinship ties (initially non-existing) were established between the subjects and objects of power, on the other, this kinship should under no circumstances become (legitimately) real, that is it must always remain artificial. With all the benefits of this kindred relationship for the parties, its artificial nature is always kept in mind and emphasized. It is noteworthy that unequal marriages for princes (Complete collection... 1997: 82) or adoption of foreigners 
(Reineggs 1974: 212) become impossible in this context. The candidate atalyks fought for the right to raise a princely son, since there were no other legitimate opportunities to acquire kinship with the prince. Why, in the absence of consanguinity in the vertical dimension, the blood relations had to be imitated? The fact is that within the power system of historical Kabardia, the kinship ties were important for functionaries not by themselves but as means of protection, patronage, and mutual assistance. Kinship is not an objective, but a way to achieve certain goals and objectives.

\section{INTERNATIONAL RELATIONS AND THE KINSHIP FACTOR}

It is impossible to overestimate the importance of the kinship ties established between the Kabardian princes and representatives of ruling groups of neighboring nations. Kinship in this case was established through atalykism, marriage, and fraternity. The princes' external policy depended heavily on the kinship ties established with representatives of the outside world. On the other hand, such ties could be the result of certain external policy preferences. In any case, the relationship through kinship would ultimately strengthen the union. Edmund Spenser noted that, 'similar to their counterparts in Europe, the Caucasian princes are fully aware of the advantages of strong family ties (italics added. - Yu.A.); consequently, they prefer to give their daughters in marriage to noble or influential chiefs of local tribes than to foreigners' (Spenser 1994: 99). The Kabardian princes established kinship through marriage with the Crimean, Nogai, Kalmyk, Georgian, Kumyk and other rulers. Marriage with some of them was more prestigious, with others - less. Nevertheless, such kinship somehow guaranteed the strength of the allied relations and justified relations and actions undesirable for third parties. The Kabardian princes would hardly ever miss the opportunity to recall the marriage between Ivan the Terrible and Maria Temryukovna. But Ivan the Terrible himself and the Russian ambassadors to Crimea and Turkey of his time, if necessary, also mentioned this episode, not as a small talk but with a definite purpose. In a number of documents devoted to negotiations between the Russian and Crimean parties on the foundation of towns by the Russians in the mouths of Sunzha and Terek rivers, one and the same justification is repeated for that construction. In 1568, in the charter of Ivan Vasilyevich to the Crimean Khan Devlet-Girey we read, 'We ordered the town on the Terek river to be set at the request of Prince Temryuk, because we appreciated him and married his daughter' (italics added. - Yu.A.). The Tsar explains that the town was built 
on the land of his relative Temryuk to protect his possessions (Archive IHS KBSC RAS. F. 1. Inv. 1. Case 11. P. 43). In the instructions for negotiating with the Crimean Khan Devlet-Girey, sent from the Posolsky Prikaz (Foreign Office of the Tsar) to the Russian ambassador to the Crimea Afanasy F. Nagoy it is strongly recommended, 'And if Khan starts asking ... why did we set the town on the Terek when the Circassians obey the Turkish Sultan, and if they demand to tear down the town on the Terek, then answer that the town on the Terek river was set at the request of Prince Temryuk, because we appreciated him and married his daughter' (italics added. - Yu.A.) (Dzamikhov 2008: 518). The same justification is offered to be voiced by the messenger to the Crimea Osoryin and the messenger to Turkey Ivan P. Novosiltsev (Dzamikhov 2008: 520-521). In his letter to the Turkish Sultan Murad in 1594, Tsar Fyodor Ivanovich also would not miss the chance to mention the marriage of Ivan Vasilyevich to Maria Temryukovna, but with a different emphasis. Here the original myth is that being the Ryazan dwellers and Russian Tsars' peasants, the Circassian princes had been serves for a long time and then they fled to the mountains but later changed their mind and bowed to Ivan Vasilievich (Archive IHS KBSC RAS. F. 1. Inv. 1. Case 11. P. 159-160). If earlier they used to say that the town had been founded on Temryuk's land, now the same Tersky town was called the ruler's town (Archive IHS KBSC RAS. F. 1. Inv. 1. Case 11. P. 132) and it gradually moved to the category of the Tsar's 'patrimonies'. Perhaps, such a transformation happened, among other things, due to establishment of kinship (real kinship by marriage, not fictitious) between the Kabardian princes represented by Temryuk and the Russian rulers represented by Ivan Vasilyevich with further emerging inheritance rights.

Meanwhile, at the time of Ivan the Terrible the Russian statehood was at a higher developmental stage than the weakly manifested Kabardian statehood. Nevertheless, the kinship together with its attributes was not excluded from political process in Russia at that time. Yuri M. Lotman noted that

when Ivan the Terrible executed not only the disgraced boyar and his family, but also all his servants, this was dictated not by an imaginary fear of revenge (since a serf from the provincial patrimony could hardly be dangerous for the Tsar!), but by the idea that in legal terms they were one person with the head of the house. The Russian people saw the terrible cruelty of the monarch as he widely applied executions to his people, but the inclusion of all members of the 
clan in the number of disgraced seemed natural to them (Lotman 1992: 13-14).

It is not surprising that the records of the Kabardian-Russian relations, kept by the tsar's clerks, often contained phrases like 'children, brothers, nephews, grandchildren and all the people in possession' of a prince (Archive IHS KBSC RAS. F. 1. Inv. 1. Case 11. P. 459-463). There was also an indicative constant requirement to take close relatives of the princes and paramount nobles as amanats (hostages) (Archive IHS KBSC RAS. F. 1. Inv. 1. Case 12. P. 103; Archive IHS KBSC RAS. F. 1. Inv. 1. Case 11. P. 445; OCSA AS KBR. F. P-1209. Inv. 6. Case 25. P. 43; Butkov 2001: 37).

One of the sources describes the dissatisfaction of Tsar Mikhail Fedorovich with the possible undesirable consequences of establishing a kinship between Kabardian and Crimean princes. The Tsar wrote to his Terek commanders Alexey Golovin and Ermolai Myasoedov that Prince Narchov Elbuzlukov gave his daughter in marriage to the Crimean prince Shangirey without Tsar's permission. The Tsar is concerned that when Narchov visited Moscow, he did not bow to him, asking permission to marriage with Shangirey and did not even mention it.

And he, Prince Narshov does that in the wrong way, forgetting our tsarist benevolence and his oath to the great sovereign. He stood under our royal high hand in direct servility in our monarchial benevolence forever relentlessly, so that being under our royal high hand, to serve the great sovereign and never join or communicate our enemies and become disobedient. And he forgot that he took his oath and went to Shangirey, and wooed him, and gave his daughter to marry Shangirey without our permission ... And he knows himself that Shangirey crosses us, his great sovereign ... (OCSA AS KBR. F. P-1209. Inv. 6. Case 19. P. 97-98).

Narchov responds to the Tsar's accusations in the following way, 'and it is in the custom, they give their daughters to other lands and the Crimea to marry their friends and enemies. And his daughter was given as a wife to Shangirey under duress, since they had a great famine in Kabardia ...' (OCSA AS KBR. F. P-1209. Inv. 6. Case 19. P. 97-98). Narchov tempered in his words a little because through established kinship the 'enemies' became 'friends' and this very fact caused Mikhail Fedorovich to be worried. The passages presented here are interesting primarily because they illustrate the state importance of kinship issues for all participants of the described event 
with an obvious priority of personal ties in arranging domestic and external policy affairs.

The scheme of atalyk relations, established with representatives of the outside world, was similar to relations established within Kabardian society: the one who gave his child to atalyk for upbringing was higher in his status than the atalyk but in this way acquired an ally in a subordinate position (even if subordination was not carried out fully, there have always been claims to this) (Glavani 1974: 159, 161; OCSA AS KBR. F. P-1209. Inv. 8. Case 5. P. 133-135). At the same time the fostered child could make the atalyk's subordinates do something, although he was not their master (unlike atalyk), yet after receiving an appropriate permission from the atalyk (Archive IHS KBSC RAS. F. 1. Inv. 1. Case 14 a. P. 86; OCSA AS KBR. F. P-1209. Inv. 8 addit. Case 25. P. 3-5). Atalyk, on the other hand, became involved in the power orbit of a patron-ally who was more powerful than himself, and thus, could set his patron-ally's matters if given such powers (Archive IHS KBSC RAS. F. 1. Inv. 1. Case 11. P. 526-527). Establishing kinship through atalyk ties with representatives of the outer circle did not so much reinforce the existing power hierarchy (as in the case of the atalykism custom inside Kabardia), but rather worked to create such a hierarchy with representatives of the outside world.

For the traditional Kabardian society, the established kinship ties not only between local and external elite were important. The category of 'kinship' and kinship ties were generally significant for international relations, bearing in mind the external links of society's different layers. Here we mean such institutions as fraternity (kunaks) (Tornau 1991: 15; Marigny 1974: 294; Blaramberg 1974: 385-386), adoption (Tornau 1991: 16; Marigny 1974: 313; Pallas 1974: 221), and hospitality (Koch 1992: 44-45). One may find the following description in the passage from the records about one of the conflicts between the Kabardians and Kalmyks made by Evliya Chelebi in the seventeenth century. In response to the Kalmyks' demand to give them the Nogai Murza Aslanbek whom they pursued and who remained under the Kabardins' patronage, the latter responded that 'the Tatar Aslanbek is a bird, he found shelter, coming to the sounds of our singing. We gave [him] yurts, became brothers. And we will not give you this man of the Nogai tribe' (Chelebi 1979: 87).

Thus, the theory and practice of establishing kinship supported and also justified certain actions in international affairs. The available evidence of the kinship established between the Kabardian princes and members of the elites of neighboring political entities, reflecting the extreme importance of kinship for the parties, does not speak exclu- 
sively of kinship. In almost all cases, the kinship is mentioned for the sake of achieving certain goals in international relations. The sources prove that one does not exist without the other since kinship was not mentioned and established for the sake of kinship itself, while the unions (symmetrical or asymmetrical) were more reliable if strengthened by kinship.

\section{TERRITORIALITY IN TRADITIONAL KABARDIAN SOCIETY}

The territoriality is most often associated with a country's division into administrative districts based not on the population division but on the territorial division. In his works Mamaikhan A. Aglarov studied territorial division, territorial relations, and territorial structure by the example of the rural community of Highland Dagestan and mostly limited himself to quoting Friedrich Engels' words (i.e., 'No longer affiliation to clan unions was of decisive significance, but exclusively the place of dwelling; not the people underwent a division, but the territory; the population in political sense turned into a simple appendage of the territory' [Aglarov 1988: 89-104]) and statements about increasing role of 'territory' for Mountainous Dagestan. Is this outdated definition of territoriality applicable in general and to traditional Kabardia in particular? It seems that it is not.

First, the traditional society could not perceive the territory abstractly apart from the people inhabiting it and from the people owning it, in order to engage in the division of the territory without prioritizing its population. So it is no coincidence that in traditional societies throughout world history, the land was designated by the names of owners or by the name of people inhabiting it. Aron Gurevich correctly noted that 'feudal property not only implies non-economic coercion, but also incorporates it as an integral, constitutive part, because feudal property was not the right of free disposal of any territory, but power over people living and working on this land' (Gurevich 1999). However, if we consider territoriality basing on the outdated definitions, then hardly any Western European country of the Middle Ages was familiar with the state as a form of institutionalized power.

Secondly, the sources on Kabardian history quite often demonstrate that Kabardian princes primarily fought for and divided the population and not only and not so much the territory. There is a vicious circle: the land was needed to attract new subjects and the residence of the prince's subjects in a particular territory and its usage allowed him to declare and confirm his rights to the land. In this sense the Abazins, subjects of the Kabardian princes, serve an indicative 
example. It was not the Abazin territory that was divided between the princes, but the Abazin people; the Crimea and the Kabardian princes, challenging their rights to the Abazins, resettled them from one place to another, but that was no question of the destiny of the territory that was supposed to remain after such a move (Archive IHS KBSC RAS. F. 1. Inv. 1. Case 14a. P. 210-212; OCSA AS KBR. F. P-1209. Inv. 17. Case 1. P. 18-20). The situation was rather similar inside Kabardia, '... Raslanbek [Kaitukin], at the demand of his brothers, began a census of villages and people, in order to divide them among brothers and thus and thus provided them with the opportunity to nomadize at will' (Archive IHS KBSC RAS. F. 1. Inv. 1. Case 14a. P. 288-289). Villages often were moved in the process.

Above we cited Dmitri M. Bondarenko's assumption that nonterritorial kinship relations are characterized by the dominance of kindred, family, and community relations in the political realm. Modern community theory is based on the recognition that a rural community is an evolving institution of class society, adapted to its interests, an institution that can be created anew and not necessarily on the basis of a primitive community (Aglarov 1988: 24-28; Alaev 2003: 213-215). Consequently, the community is not always a relic of primitiveness or a natural phenomenon opposed to human-induced one - the state (Evseenko 2003: 11).

It is in the vein of this new direction of the community theory that for several decades Kazharov has been elaborating the patrimonial community model. The essence of the concept he presented is as follows: patrimony is the basic structural principle of the social organization of the Kabardian society. In addition, the patrimonial structural principle obtained an 'ultimate' development in the Kabardian traditional society while the Kabardian socio-economic system of feudalism should be assessed as developed feudalism. The communityrelated element is observed only in farming. During farm works, princes would formally become 'members of the community,' performing their share of duties and contributing to a successful completion of the common cause. But the land was actually the feudal property of the patrimony owner, who possessed the village and the village lands. The community frame became important only during agricultural work and only because it was beneficial for landowning feudal lords who were interested in a steady production flow and inflow of taxes (Kazharov 1994, 2007).

In view of all the above said, the manifestations of territoriality in the traditional Kabardian society can be presented as follows: 
1) The Kabardian princes had the right and opportunities to divide the country's territory into parts regardless of the traditional division determined by the detached existence of the clannish groups (Nogmov 1994: 112-113, 138). The division of the country's territory served the princes' political interests and administrative necessities. And it must be assumed that 'administrative districts' of a traditional society are somewhat different from the modern understanding and their creation could be justified by long-standing customs and traditions despite of their formation by the will and efforts of the 'top' rather than the 'bottom' of the society.

2) The kinship and its attributes are not eradicated by dividing the country's territory into 'administrative districts' at the rulers' request. Since administrative apparatus was underdeveloped, the structural units of traditional Kabardian society, welded by the kinship factor and having the right to manage their internal ties, served as administrative units in the broader context of state policy. The same refers to the elements of communality. The community was adapted to the needs of traditional Kabardian society (and in particular, of its elite) of the period and there was virtually no element of self-government (although nominally such elements existed and were actually a mixture of tribute to tradition, populism and production/consumer necessity).

3) The Kabardian princes did not consider the territory they divided separately from population. The Kabardian princes (pshi) fought for the population so there was no need for them to prove their sovereign ownership of the Kabardian land, since it was self-evident. This does not prove the marginal significance of territory and its division but means an unseparated perception of population and territory together with the indisputable right of the supreme ownership of land exercised by the princes on Kabardian territory with the right of vassals to transit to new suzerain and with inheritance law. The rulers, being relatives, shared the population/territory and yet, they had not any kinship relations with the population/subjects.

4) The Kabardian settlements (kuazha) belonged to the owners. Despite the preservation of 'settlement by clans' or the 'patronymic principle of settlement' (this state of affairs became traditional, since cohabitation of a larger number of generations of relatives met the ruling elite's interests), the settlement structure fitted the complex hierarchical social structure of traditional Kabardian society (Archive IHS KBSC RAS. F. 1. Inv. 1. Case 23. P. 14turn-5turn.; Kumykov 1965; Mambetov 1971: 67-72; Kobychev 1982: 20-25). The horizontal kinship ties in the settlement were overlapped by vertical links, since management functions and decision-making were in the sphere 
of vertical links. Within a settlement, the dominant factor of existence was the neighborhood-territorial relations between the rulers and the ruled and not the neighborhood of relatives, often observed in the settlement quarters.

5) The mobility of Kabardian settlements, described in the sources, is not the evidence of the absence of administrative division and of marked boundaries in traditional Kabardian society. Each settlement had its strictly defined arable and grazing lands, within which it moved under certain circumstances. The main 'administrators' and rulers of Kabardia were pshi. The territorial possessions of princes, princely families and princely groups were always defined by wellknown and delineated borders.

6) The traditional Kabardian society was distinguished by the ethnic heterogeneity provided both by voluntary and involuntary inclusion of foreigners to the subjects of the Kabardian princes. Often it was not just joining, but also relocation (Archive IHS KBSC RAS. F. 1. Inv. 1. Case 5. P. 67-68; Archive IHS KBSC RAS. F. 1. Inv. 1. Case 14a. P. 210-212; OCSA AS KBR. F. 1. Inv. 1. Case 49. P. 2424turn.; OCSA AS KBR. F. P-1209. Inv. 17. Case 1. P. 18-20). The penetration of a foreign elements influenced the structurie of the residence territory of traditional Kabardian society.

\section{CONCLUSION}

Despite the fact that the kinship/territoriality dichotomy takes leading positions, the researchers come to the conclusion about the artificial character of this opposition and its incompatibility with reality. The kinship element holds important positions in societies with developed statehood. The researchers, elaborating the early state concept, recognize that the state is still based on territorial ties, although the possible presence of a significant proportion of family ties is not excluded. The study of the correlation between consanguinity and territorial ties in traditional Kabardian society dispels the idea about the fundamental role of consanguinity in the power relations network. Nevertheless, the kinship ties have an important role in the structure of social ties and relations of Kabardia of the sixteenth-eighteenth centuries. In this regard, any attempts to discern the peculiarities of territorial relations in the traditional Kabardian society, while ignoring the kindred ones, are doomed to failure. In this case, the use of the formula 'coexistence of kinship and territorial ties with the domination of the latter' is not appropriate either. The territorial connections and ties were not just dominant, they were the basis of power links and relations in the situation 1) of a complete absence of real kinship between the rulers and 
the ruled; 2) of the existing practice of imitation of kinship, realized as a relatively strong attachment in a society where there was a theory and practice of counteracting the establishment of real kinship between members of different social strata; and 3) affiliation of kinship ties to the sphere of traditions and ideology when the ruling elite realized their high functionality and effectiveness in the management of people and the country.

Thus, the acceptable degree of the presence of kinship ties and the necessary share of territorial ties observed in the Kabardian society fully corresponds to the perceptions of researchers working on the early state concept. The study of the manifestations of the existing kinship and territorial principles of societal organization in Kabardia in the sixteenth-eighteenth centuries does not give any grounds for its exclusion from the list of states of the North Caucasus of the epoch of traditional societies, rather the contrary.

\section{NOTES}

${ }^{1}$ The sources indicate that the basic unit of the kinship system of traditional Kabardian society was a large family [unezeshzahes (Musukaev and Pershits 1992: 13)]: ' ... every family, from great-grandfather to the latest generation, lives inseparably and food is consumed from one pot and due to this, people here do not say how many families or courtyards, but how many pots' (Gardanov 1956: 143); '... Kabardians are not like other nations, where each family lives in an individual household, but within estates called the courtyard, surrounded by a fence, housing unequal number of families - from two-three to ten families lived under one roof (Novitsky, Mogukorov N.d.: 2). The fragmentation of a large family into small ones at the level of objects of power, that is, the majority of the nobility and the peasantry was not welcomed and it was even limited in the case of the peasantry (Nagoev 2007: 360 [Note by Major J. Shardanov about estate relations in Kabar$d a]$ ). But in the case of the main subjects of power - pshi, living of ancestral princes and descendant ones, was not allowed. The young prince, returned by atalyk to the princely family, should dwell in a separate household.

${ }^{2}$ Numerous princely dynasties descended from a single ancestor - the legendary Inal who (according to the legend) was in turn a descendant of Kes. The origin of the latter was derived from the clan of Arabian rulers. The affirmation of Islam among Kabardians contributed to the addition of information on the belonging of Inal to the Arab tribe of Kureishites to which the prophet Mohammed also belonged, to the Arabian genealogy of the princely family. After Inal's death, his sons divided Circassia into fiefdoms. The references to the foreign or divine origin of the Kabardian princes were designed to exalt them above the rest of the population and confirm their right to rule and high status.

${ }^{3}$ The confrontation of the princely feudal groups in Kabardia led to the Malka battle in 1641 with participation of external forces. After the 164levents, the disintegration of Kabardia into Major Kabardia (from Malka to Urukh) and Minor Kabardia (from Urukh to Middle Terek) occurred. In Major Kabardia there were three princely fiefdoms: Zhambolat's (which was later divided into two - Kai- 
tuko's and Bekmurza's), Atazhuko's and Misost's. In Minor Kabardia there were two: Talostan's and Gelyakhstan's.

${ }^{4}$ Translated as princely fence, i.e. pshikeu - an official under the prince, the executor of his errands.

${ }^{5}$ Two 'political' groups in the Major Kabardia, which adhered to the Russian and Crimean foreign policy orientation. Depending on the situation, the parties changed their preferences and allies, so their foreign policy orientation was not constant and unchanged.

\section{REFERENCES}

Aglarov, M. A. 1988. Village Community in Highland Daghestan in the $17^{\text {th }}-$ Early 19th Centuries (A Study of Interaction of Economic Forms, Social Structures and Ethnicity). Moscow: Nauka. Original in Russian (Агларов, М. А. Сельская община в Нагорном Дагестане в XVII - начале ХІХ в. (Исследование взаимоотношения форм хозяйства, соииальных структур и этноса). М.: Наука).

Alaev, L. В. 2003. Medieval India. SPb.: Aleteiya. Original in Russian (Алаев, Л. Б. Средневековая Индия. СПб.: Алетейя).

Bgazhnokov, B. Kh. 2004. Princely Family Sunchaleevyh in the History of Kabarda of the $17^{\text {th }}$ Century. In Genealogy of the South of Russia. Materials of the All-Russian Scientific Conference (June 25-27, 2004) (pp. 101105). Nalchik: Poligrafservis i T. Original in Russian (Бгажноков, Б. Х. Княжеская семья Сунчалеевых в истории Кабарды XVII века. Генеалогия Юга России. Материаль Всероссийской научной конферениии (25-27 июня 2004 г.), с. 101-105. Нальчик: Полиграфсервис и Т).

Bgazhnokov, B. Kh., Berzegova, S. D. 2005. Semantics and Pragmatics of the Adyghe Kinship Terms. Istoricheskii vestnik 1: 329-340. Original in Russian (Бгажноков, Б. Х., Берзегова, С. Д. Семантика и прагматика адыгских терминов родства. Исторический вестник 1: 329-340).

Blaramberg, I. F. 1974. Historical, Topographical, Statistical, Ethnographic and Military Description of the Caucasus. In Gardanov, V. K. (ed.), Adyghes, Balkars and Karachays in the Reports of European Authors of the $13^{\text {th }}-19^{\text {th }}$ centuries (ABKREA) (pp. 353-434). Nalchik: El'brus. Original in Russian (Бларамберг, И. Ф. Историческое, топографическое, статистическое, этнографическое и военное описание Кавказа. Адыги, балкариь и карачаевцы в известиях европейских авторов (АБКИЕА) XIII-XIX вв. / ред. Гарданов, В. К., с. 353-434. Нальчик: Эльбрус).

Bloch, M. 2003. Feudal Society. Transl. from fr. M.Yu. Kozhevnikova. Moscow: Izdatel'stvo im. Sabashnikovykh. Original in Russian (Блок, М. Феодальное общество / пер. с фр. М. Ю. Кожевниковой. М.: Издательство им. Сабашниковых).

Bondarenko, D. M. 2005. A Homoarchic Alternative to the Homoarchic State: Benin Kingdom of the $13^{\text {th }}-19^{\text {th }}$ Centuries. Social Evolution \& History 4 (2): 18-88. 
Bondarenko, D. M. 2008. Kinship, Territoriality and the Early State Lower Limit. Social Evolution \& History. Thirty years of Early State research. Special issue. Ed. by H. J. M. Claessen, R. Hagesteijn, P. van de Velde 7 (1): 19-53.

Bondarenko, D. M., Grinin, L. E., and Korotayev, A. V. 2002. Alternative Pathways of Social Evolution. Social Evolution \& History 1: 54-79.

Bondarenko, D. M., Nemirovskiy, A. A. 2009. Introduction. In The Ruler and His Subjects: Socio-Cultural Norm and Restrictions of the Individual Power (pp. 5-17). Moscow: Institut Afriki RAN. URL: https://www.inafran.ru/sites/default/files/page file/pravitel.pdf (date of access: 21.02.2019). Original in Russian (Бондаренко, Д. М., Немировский, А. А. Введение. Правитель и его подданные: социокультурная норма и ограничения единоличной власти, с. 5-17. М.: Институт Африки РAH. URL: https://www.inafran.ru/sites/default/files/page_file/ pravitel.pdf [дата обращения: 21.02.2019]).

Bukalova, V. M. (ed.) 1957. Kabardino-Russian Relations in the $16^{\text {th }}-18^{\text {th }}$ Centuries. Documents and Materials: in 2 vols. Vol. 2: $18^{\text {th }}$ century. Moscow: AS USSR. Original in Russian (Кабардино-русские отночения в XVI-XVIII вв. Документы и материаль: в 2-х т. Т. 2: XVIII в. / ред. Букалова, В. М. Москва: АН СССР).

Butkov, P. G. 2001. Materials for the New History of the Caucasus from 1722 to 1803. Extracts. Nalchik: El'-Fa. Original in Russian (Бутков, П. Г. Материаль для новой истории Кавказа с 1722-го по 1803 год. Извлечения. Нальчик: Эль-Фа).

Chabal, P., Feinman, G., and Skalník, P. 2004. Beyond States and Empires: Chiefdoms and Informal Politics. Social Evolution \& History 3 (1): 22-40.

Chelebi, Evliya. 1979. Travel Book (Extracts from the Writings of a $17^{\text {th }}$ Century Turkish Traveler). Issue 2. Lands of the North Caucasus, the Volga region and the Don Region. Moscow: Nauka. Original in Russian (Челеби, Эвлия. Книга путешествия (Извлечения из сочинения турецкого путешественника XVII века). Вып. 2. Земли Северного Кавказа, Поволжся и Подонья. М.: Наука).

Claessen, H. J. M. 2002. Was the State Inevitable? Social Evolution \& History 1 (1): 101-117.

Claessen, H. J. M. 2005. Early State Intricacies. Social Evolution \& History 4 (2): 151-158.

Claessen, H. J. M. 2008. Before the Early State and After: An Introduction Social Evolution \& History. Thirty years of Early State research. Special issue. Ed. by H. J. M. Claessen, R. Hagesteijn, P. van de Velde 7 (1): 4-18.

Claessen, H. J. M. 2012. Reconsideration of a Reformulation. Social Evolution \& History 11 (2): 36-43.

Claessen, H. J. M. 2016. The Emergence of Pristine States. Social Evolution \& History 15 (1): 3-57. 
Complete Collection of Kabardian Ancient Rites. 1997. In Legal Norms of the Circassians and Balkar-Karachai in the $15^{\text {th }}-19^{\text {th }}$ centuries (pp. 79106). Maikop: Meoty. Original in Russian (Полное собрание кабардинских древних обрядов. Правовые нормы адыгов и балкарокарачаевиев в XV-XIX вв., с. 79-106. Майкоп: Меоты).

Delpozzo I. P. 1808. Notes on Big and Small Kabarda. Archive IHS KBSC RAS. F. 1. Inv. 1. Case 2. Original in Russian (Дельпоццо, И. П. Записки о Большой и Малой Кабарде (1808 г.). Архив ИГИ КБНЦ РАН. Ф. 1. On. 1. Д. 2.).

Demidova N. F., Kusheva E. N., Persov A. M. (eds.) 1957. KabardinoRussian Relations in the $16^{\text {th }}-18^{\text {th }}$ Centuries. Documents and materials. 2 vols. Vol. 1: $16^{\text {th }}-17^{\text {th }}$ centuries. Moscow: AS USSR. Original in Russian (Кабардино-русские отношения в XVI-XVIII вв. Документы и материальв: в 2-х т. Т. 1: XVI-XVII вв. / ред. Демидова, Н. Ф., Кушева, Е. Н., Персов А. М. Москва: АН СССР).

Dzamikhov, K. F. 2008. Kabarda and Russia in the Political History of the Caucasus (studies and materials). In Dzamikhov, K. F. (ed.), Adyghes: Milestones of History (pp. 437-668). Nalchik: El'brus. Original in Russian (Дзамихов, К. Ф. Кабарда и Россия в политической истории Кавказа (исследования и материалы). Дзамихов, К. Ф. Адыги: вехи истории, с. 437-668. Нальчик: Эльбрус).

Engels, F. 1986. Origin of Family, Private Property and State. In Marks K., Engel's F. Selected Works. 3 vols. Vol. 3. Moscow: Politizdat. Original in Russian (Энгельс Ф. Происхождение семьи, частной собственности и государства. Маркс, К., Энгельс, Ф. Избранные произведения: в 3 т. Т. 3. М.: Политиздат).

Evseenko, T. P. 2003. On the Issue of "Civil Society" in the Ancient World. Antichnaya drevnost' $i$ srednie veka 34: 9-22. Original in Russian (Евсеенко, Т. П. К вопросу о «гражданской общине» в древнем мире. $A$ тичная древность и средние века 34: 9-22).

Gardanov, B. A. 1956. Description of the Kabardian People, Compiled in 1784 by P. S. Potyomkin. In Collection of articles on the history of Kabarda. Iss. 5 (pp. 122-151). Nalchik: Kabardinskoe knizhnoe izdatel'stvo. Original in Russian (Гарданов, Б. А. Описание кабардинского народа, составленное в 1784 году П.С. Потемкиным. Сборник статей по истории Кабарды. Bылn. 5, с. 122-151. Нальчик: Кабардинское книжное издательство).

Gardanov, V. K. 1967. The Social Structure of the Adyghe Peoples (18 ${ }^{\text {th }}-$ first half of the $19^{\text {th }}$ century). Moscow: Nauka. Original in Russian (Гapданов, В. К. Общественнылй строй адыгских народов (XVIII - первая половина XIX века). М.: Наука).

Glavani, K. 1974. Description of Circassia (1724). In Gardanov, V. K. (ed.), Adyghes, Balkars and Karachays in the reports of European authors of the 
$13^{\text {th }}-19^{\text {th }}$ centuries $(A B K R E A)$ (pp. 156-173). Nalchik: El'brus. Original in Russian (Главани, Ксаверио. Описание Черкесии (1724). Адыги, балкариы и карачаевцы в известиях европейских авторов (АБКИЕА) ХІІІ$X I X$ вв. / ред. Гарданов, В. К., с. 156-173. Нальчик: Эльбрус).

Grabovsky N.F. 1870. Essay on the Court and Criminal Offenses in the Kabardin District. In Collection of Information about the Caucasian Highlanders (pp. 1-72). Tiflis, 1870. Iss. 4. Original in Russian (Грабовский Н. Ф. Очерк суда и уголовных преступлений в Кабардинском округе. Сборник сведений о кавказских горияах 4: 1-72).

Grinin, L. E. 2003. The Early State and its Analogues. Social Evolution \& History 2 (1): 131-176.

Grinin, L. E. 2006. The Early State and its Analogues. In Grinin, L. E. et al. (eds.), The Early State, Its Alternatives and Analogues (pp. 85-164). Volgograd: Uchitel. Original in Russian (Гринин, Л. Е. Раннее государство и его аналоги. Раннее государство, его альтернативы и аналоги: Сб. статей / под ред. Л.Е.Гринина и др., с. 85-164. Волгоград: Учитель).

Grinin, L. E. 2007. The State and the Historical Process. The Era of State Formation: The General Context of Social Evolution at State Genesis. Moscow: URSS. Original in Russian (Гринин, Л. Е. Государство и исторический процесс. Эпоха формирования государства: Общий контекст социальной эволюции при образовании государства. М.: КомКнига).

Grinin, L. E., and Korotayev, A. V. 2012. Emergence of Chiefdoms and States: A Spectrum of Opinions. Social Evolution \& History 11 (2): 191-204.

Gurevich, A. Ya. 1977. Norwegian Society in the Early Middle Ages. Moscow: Nauka Original in Russian (Гуревич, А. Я. Норвежское общество в раннее Средневековье. М.: Наука).

Gurevich, A. Ya. 1999. The Beginning of Feudalism in Europe. In Gurevich, A. Ya. Selected Works. 2 vols. Vol. 1. Moscow-SPb: TsGNII INION RAN. Original in Russian (Гуревич, А. Я. Начало феодализма в Eвpone. По кн. Избранные труды: в 2 т. Т. 1. М-СПб. ЦГНИИ ИНИ$\mathrm{OH} \mathrm{PAH})$.

Karlgof, N. I. 2004. On the Political Structure of the Circassian Tribes Inhabiting the North-Eastern Coast of the Black Sea. In Landscape, Ethnographic and Historical Processes in the North Caucasus in the $19^{\text {th }}-$ beginning of the $20^{\text {th }}$ century (pp. 104-135). Nalchik: El'-Fa. Original in Russian (Карлгоф, Н. И. О политическом устройстве черкесских племен, населяющих северо-восточный берег Черного моря. Ландшафт, этнографические и исторические процессы на Северном Кавказе в $X I X-$ нач. $X X$ в., с. 104-135. Нальчик: Эль-Фа).

Kazharov, V. Kh. 1982. Rural Community among the Adyghe in the First Half of the $19^{\text {th }}$ Century (Land Relations): Abstract of the thesis. Moscow. Original in Russian (Кажаров, В. Х. Сельская община у адыгов в пер- 
вой половине XIX века (поземельные отнотения): автореф. дис. ... канд. ист. наук. Москва).

Kazharov, V. Kh. 1992. The Main Social Unit of the Adyghe Society in the $18^{\text {th }}$ - first half of the $19^{\text {th }}$ Century. In Actual Problems of Feudal Kabar$d a$ and Balkaria (pp. 7-51). Nalchik: Poligrafkombinat im. Revolyutsii 1905 goda Goskomizdata KBSSR. Original in Russian (Кажаров, В. X. Основная социальная единица адыгского общества в XVIII - первой половине XIX века. Актуальные проблемы феодальной Кабарды и Балкарии, с. 7-51. Нальчик: Полиграфкомбинат им. Революции 1905 года Госкомиздата КБССР).

Kazharov, V. Kh. 1994. Traditional Social Institutions of Kabarda and Their Crisis at the end of $18^{\text {th }}$ - first half of the $19^{\text {th }}$ Century. Nalchik: El'-Fa. Original in Russian (Кажаров, В. Х. Традиционные общественные институты Кабарды и их кризис в конще XVIII - первой половине XIX века. Нальчик: Эль-Фа).

Kazharov, V. Kh. 2007. Kabardian Patrimony-Community of the Times of the Russian Conquest of the North-Western Caucasus. In Bobrovnikov V. O., Babich, I. L. (eds.), North Caucasus within the Russian Empire (pp. 347369). Moscow: Novoe literaturnoe obozrenie. Original in Russian (Кажаров, В. Х. Кабардинская вотчина-община времен русского завоевания Северо-Западного Кавказа. Северный Кавказ в составе Российской империи / ред. Бобровников, В. О., Бабич, И. Л., с. 347-369. М.: Новое литературное обозрение).

Khan-Girey. 2008. Papers on Cherkessia. Nalchik: El'-Fa. Original in Russian (Хан-Гирей. Записки о Черкесии. Нальчик: Эль-Фа).

Khotko, S. Kh. 2009. Eastern Zakubanye in the Context of Ethno-Social and Demographic History of Cherkessia. In Besleney - the bridge of Circassia. Issues of historical demography of the Eastern Zakubanye. The $13^{\text {th }}-19^{\text {th }}$ centuries. Collection of documents and materials. Compilation and introductory article by S. Kh. Khotko. Maikop: OAO «Poligraf-Yug». Original in Russian (Хотко, С. Х. Восточное Закубанье в контексте этносоциальной и демографической истории Черкесии. Бесленей-мост Черкесии. Вопросы исторической демографии Восточного Закубанья. XIIIXIX вв. Сборник документов и материалов. Составление и вступительная статья Хотко, С.Х. Майкоп: ОАО «Полиграф-Юг»).

Klaproth, H.-J. 1974. Journey to the Caucasus and Georgia in 1807-1808. In Gardanov, V. K. (ed.), Adyghes, Balkars and Karachays in the reports of European authors of the $13^{\text {th }}-19^{\text {th }}$ centuries (ABKREA) (pp. 235-280). Nalchik: El'brus. Original in Russian (Клапрот, Г.-Ю. Путешествие по Кавказу и Грузии, предпринятое в 1807-1808 гг. Адыги, балкариьы и карачаевиьы в известиях европейских авторов (АБКИЕА) ХIII-ХIХ вв. / ред. Гарданов, В. К., с. 235-280. Нальчик: Эльбрус).

Kobychev, V. P. 1982. Settlements and Dwellings of the North Caucasus Peoples in the $19^{\text {th }}-20^{\text {th }}$ centuries. Moscow: Nauka. Original in Russian 
(Кобычев, В. П. Поселения и жилище народов Северного Кавказа в $X I X-X X$ вв. М.: Наука).

Koch, K. 1992. Circassians. Adygi. Kul'turno-istoricheskii zhurnal. 4: 44-75. Original in Russian (Кох, К. Черкесы. Адыги. Культурноисторический журнал 4: 44-75).

Kokiev, G. A. 2005. The History of Kabardino-Balkaria in the Works of G. A. Kokiev. In Mambetov, G. Kh. (ed.), Collection of Articles and Documents. Nalchik: El'-Fa. Original in Russian (История Кабардино-Балкарии в трудах Г.А. Кокиева. Сборник статей и документов. Выявление, археография, составление, вступительная статья Г.Х. Мамбетова. Нальчик: Эль-Фа).

Korolenkov, A. V. 2009. 'Your father is older than all of us, but he cannot live with us': Prince, the Norm and the Reaction to its Violation in preMongol Russia. In The Ruler and His Subjects: Socio-Cultural Norm and Restrictions of the Individual Power (pp. 214-237). Moscow: Institut Afriki RAN. URL: https:/www.inafran.ru/sites/default/files/page_file/ pravitel.pdf. Accessed February 21, 2019. Original in Russian (Короленков, А. В. «Всих нас стареи отець твои, но с нами не умееть жити»: князь, норма и реакция на её нарушение в домонгольской Руси. Правитель и его подданные: сочиокультурная норма и ограничения единоличной власти, с. 214-237. М.: Институт Африки PAH. URL: https://www.inafran.ru/sites/default/files/page_file/pravitel.pdf [дата обращения: 21.02.2019]).

Kosven, M. O. 1961. Ethnography and History of the Caucasus. Moscow: Vostochnaya literatura. Original in Russian (Косвен, М. О. Этнография и история Кавказа. М.: Восточная литература).

Kradin, N. N. 2006. Archaeological Signs of Civilization. In Grinin, L. E. et al. (eds.) The Early State, Its Alternatives and Analogues (pp. 184-210). Volgograd: Uchitel. Original in Russian (Крадин, Н. Н. Археологические признаки цивилизации. Раннее государство, его альтернативы и аналоги: Сб. статей / ред. Гринин, Л. Е. и др., с. 184-210. Волгоград: Учитель).

Kubbel, L. E. 1988. Essays of Potestary-Political Ethnography. Moscow: Nauka. Original in Russian (Куббель, Л. Е. Очерки потестарнополитической этнографии. М.: Наука).

Kumykov, T. Kh. 1954. On the Question of the Social Order of Kabarda on the Eve of the Reform of 1861. Uchenye Zapiski Kabardinskogo NauchnoIssledovatel'skogo Instituta 9: 44-97. Original in Russian (Кумыков, Т. Х. К вопросу об общественном строе Кабарды накануне реформы 1861 года. Ученые записки КНИИ 9: 44-97).

Kumykov, T. Kh. 1965. Places of Settlement of Kabardins and Balkars in the $40 \mathrm{~s}-60 \mathrm{~s}$ of the $19^{\text {th }}$ century. Uchenye Zapiski Kabardino-Balkarskogo Nauchno-Issledovatel'skogo Instituta. 23: 148-159. Original in Russian 
(Кумыков, Т. Х. Расселение кабардинцев и балкарцев в 40-60-х годах XIX века. Ученые записки КБНИИ 23: 148-159).

Kusheva, E. N. 1956. Socio-Economic and Political Relations in Kabarda in the $16^{\text {th }}-17^{\text {th }}$ centuries. In Collection of articles on the history of Kabarda. Iss. 5 (pp. 97-121). Nalchik: Kabardinskoe knizhnoe izdatel'stvo. Original in Russian (Кушева, Е. Н. Социально-экономические и политические отношения в Кабарде в XVI-XVII вв. Сборник статей по истории Кабарды. Вып. 5, с. 97-121. Нальчик: Каб. книжное изд-во).

Kusheva, E. N. 1963. The Peoples of the North Caucasus and their Ties with Russia (the second half of the $16^{\text {th }}-30$ s of the $17^{\text {th }}$ century). Moscow: AS USSR. Original in Russian (Кушева, Е. Н. Народы Северного Кавказа и их связи с Россией (вторая половина XVI - 30-е г2. XVII века). Нальчик: Изд-во АН СССР).

Lotman, Yu. M. 1992. About Semiosphere. In Lotman, Yu. M. Selected articles. 3 vols. Vol. 1. Articles on Semiotics and Typology of Culture (pp. 11-24). Tallinn: Aleksandra. Original in Russian (Лотман, Ю. М. О семиосфере. Избранные статьи в трех томах. Том 1. Статьи по семиотике и типологии культуры, с. 11-24. Таллинн: Александра).

Mambetov, G. Kh. 1971. The Material Culture of the Rural Population of Kabardino-Balkaria (second half of the $19^{\text {th }}$ - the sixties of the $20^{\text {th }}$ century). Nalchik: El'brus. Original in Russian (Мамбетов, Г. Х. Материальная культура сельского населения Кабардино-Балкарии (вторая половина XIX-60е годы XX века). Нальчик: Эльбрус).

Marigny, T. de. 1974. Travels to Circassia. In Gardanov, V. K. (ed.), Adyghes, Balkars and Karachays in the Reports of European Authors of the $13^{\text {th }}-19^{\text {th }}$ centuries (ABKREA) (pp. 291-321). Nalchik: El'brus. Original in Russian (Мариньи, Тебу де. Путешествия в Черкесию. Адыги, балкариь и карачаевцы в известиях европейских авторов (АБКИЕА) XIII-XIX вв. / ред. Гарданов, В. К., с. 291-321. Нальчик: Эльбрус).

Monpere Dubois, F. de. 1974. Journey through the Caucasus, to the Circassians and Abkhazians, to Colchia, Georgia, Armenia and the Crimea. In Gardanov, V. K. (ed.), Adyghes, Balkars and Karachays in the reports of European authors of the $13^{\text {th }}-19^{\text {th }}$ centuries (ABKREA) (pp. 435-458). Nalchik: El'brus. Original in Russian (Монпере, Фредерик Дюбуа де. Путешествие по Кавказу, к черкесам и абхазцам, в Колхидию, Грузию, Армению и в Крым. Адыги, балкариьы и карачаевцьь в известиях европейских авторов (АБКИЕА) XIII-XIX вв. / ред. Гарданов, В. К., c. 435-458. Нальчик: Эльбрус).

Musukaev, A. I., Pershits, A. I. 1992. Public Traditions of Kabardins and Balkars. Nalchik: Poligrafkombinat im. Revolyutsii 1905 g. Original in Russian (Мусукаев, А. И., Першиц, А. И. Народные традиции кабардинцев и балкарцев. Нальчик: Полиграфкомбинат им. Революции 1905 г.). 
Nagoev, M. B. 2007. Note by Major Ya. Shardanov about Class Relations in Kabarda. In Nagoev, M. B. Socio-Political Thought of the Adyghe in the First Half of the $19^{\text {th }}$ Century: Researches and Materials (pp. 349-382). Nalchik: El'-Fa. Original in Russian (Нагоев, М. Б. Записка майора Я. Шарданова о сословных отношениях в Кабарде // Общественнополитическая мысль адыгов в первой половине ХІХ века: исследования и материалы, с. 349-382. Нальчик: Эль-Фа).

Naloeva, E. Dzh. 1968. On the issue of social relations in Kabarda in the first half of the 18th century. Vestnik Kabardino-Balkarskogo NauchnoIssledovatel'skogo Instituta 1: 61-81. Original in Russian (Налоева, Е. Ж. К вопросу о социальных отношениях в Кабарде в первой половине XVIII века. Вестник КБНИИ 1: 61-81).

Naloeva, E. Dzh. 1972. On the Question of the State-Political System of Kabarda in the first half of the $18^{\text {th }}$ century. Vestnik Kabardino-Balkarskogo Nauchno-Issledovatel'skogo Instituta 6: 69-87. Original in Russian (Налоева, Е. Дж. К вопросу о государственно-политическом строе Кабарды первой половины XVIII века. Вестник КБНИИ 6: 69-87).

Naloeva, E. Dzh. 1980. On the Peculiarities of Kabardian feudalism. In Gugov, R. Kh., Sokurov, V. N. (eds.), From the History of Feudal Kabarda and Balkaria (pp. 5-27). Nalchik: El'brus. Original in Russian (Налоева, Е. Дж. Об особенностях кабардинского феодализма. Из истории феодальной Кабарды и Балкарии. редкол.: Гугов, Р. Х., Сокуров, В. Н., c. 5-27. Нальчик: Эльбрус).

Nazarenko, A. V. 1986. Generic suzerainty of the Rurikovichs over Russia (the $10^{\text {th }}-11^{\text {th }}$ centuries). In The Most Ancient States on the Territory of the USSR (pp. 149-157). Moscow: Nauka. Original in Russian (Назаренко, A. В. Родовой сюзеренитет Рюриковичей над Русью (X-XI вв.). Древнейшие государства на территории СССР, с. 149-157. М.: Наука).

Nogmov, Sh. 1994. The History of the Adyghe People. Nalchik: El'brus. Original in Russian (Ногмов, Ш. История адыхейского народа. Нальчик: Эльбрус).

Note on privileged estates of the Kabardin district. 1997. In Dumanov, Kh. M. (ed.), Legal norms of the Adygs and Balkar-Karachai in the $15^{\text {th }}$ $19^{\text {th }}$ Centuries (pp. 206-218). Maikop: Meoty. Original in Russian (3aписка о привилегированных сословиях кабардинского округа. Правовые нормы адыгов и балкаро-карачаевцев в XV-XIX вв., с. 206-218. Майкоп: Меоты).

Novitsky, G. V., Mogukorov, P. D. N.d. From a Geographical, Statistical Survey of the Land Inhabited by the People of Adyghe. Part describing Kabardia. Archive IHS KBSC RAS. Fund 1. Inventory 2. Case 38b. Original in Russian (Новицкий, Г. В., Могукоров, П. Д. Из географического, статистического обозрения земли, населенной народом Адехе. Часть, описывающая Кабарду. Архив ИГИ КБНЦ РАН. Ф. 1. On. 2. Д. 38б). 
Pallas, P. S. 1974. Notes about the Journeys to the Southern Governorships of the Russian State in 1793 and 1794. In Gardanov, V. K. (ed.), Adyghes, Balkars and Karachays in the reports of European authors of the $13^{\text {th }}-$ $19^{\text {th }}$ centuries (ABKREA) (pp. 214-224). Nalchik: El'brus. Original in Russian (Паллас, Петр Симон. Заметки о путешествиях в южные наместничества Российского государства в 1793 и 1794 гг. Адыги, балкариы и карачаевцьы в известиях европейских авторов (АБКИЕА) XII--XIX вв. / ред. Гарданов, В. К., с. 214-224. Нальчик: Эльбрус).

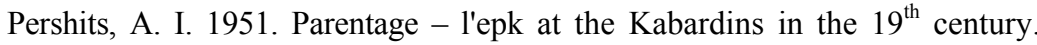
Sovetskaya Etnografiya 1: 177-180. Original in Russian (Першиц, А. И. Фамилия - лъэпкъ у кабардинцев в XIX веке. Советская этнография 1: 177-180).

Potocki, J. 1974. Journey to the Astrakhan and Caucasian Steppes. In Gardanov, V. K. (ed.), Adyghes, Balkars and Karachays in the Reports of European Authors of the $13^{\text {th }}-19^{\text {th }}$ Centuries (ABKREA) (pp. 225-234). Nalchik: El'brus. Original in Russian (Потоцкий, Я. Путешествие в Астраханские и Кавказские степи. Адыги, балкариы и карачаевцы в известиях европейских авторов (АБКИЕА) XIII-XIX вв. / ред. Гарданов, В. К., c. 225-234. Нальчик: Эльбрус).

Reineggs, Jacob. 1974. General Historical and Topographical Description of the Caucasus. In Gardanov, V. K. (ed.), Adyghes, Balkars and Karachays in the reports of European authors of the $13^{\text {th }}-19^{\text {th }}$ centuries (ABKREA) (pp. 209-213). Nalchik: El'brus. Original in Russian (Рейнеггс, Я. Всеобщее историко-топографическое описание Кавказа. Адыги, балкарцы и карачаевцы в известиях европейских авторов (АБКИЕА) ХІІІ$X I X$ вв. / ред. Гарданов, В. К., с. 209-213. Нальчик: Эльбрус).

Sherieva, N. G. 2005. The Concepts of 'Revenge' and 'Price of Blood': To the Question of Ethno-Linguistic Analysis of terms. Istoricheskii Vestnik 1: 341-348. Original in Russian (Шериева, Н. Г. Понятия «лъы щІэжын» и «льы уасэ»: к вопросу об этнолингвистическом анализе терминов. Исторический вестник 1: 341-348).

Siver, A. V. 2007. Princely Countries: The Experience of Comparing Princely Kabarda and Ancient Russia. Istoricheskii Vestnik 6: 39-76. Original in Russian (Сивер, А. В. Державы князей: опыт сравнения княжеской Кабарды и Древней Руси. Исторический Вестник 6: 39-76).

Spenser, E. 1994. Journyes to Cherkessia. Maikop: RIPO «Adygeya». Original in Russian (Спенсер, Э. Путешествия в Черкесию. - Майкоп: РИПО «Адыгея»).

Stal, K. F. 2001. Ethnographic Essay on the Circassian People. In Russian Authors of the $19^{\text {th }}$ Century on the Peoples of the Central and North-West Caucasus. 2 vols. Vol. 1 (pp. 187-278). Nalchik: El'-Fa. Original in Russian (Сталь, К. Ф. Этнографический очерк черкесского народа. Русские авторы ХІХ века о народах Центрального и Северо-Западного Кавказа: в 2-х т. Т. 1, с. 187-278. Нальчик: Эль-Фа). 
Studenetskaya, E. N. 1950. On a Large Family of Kabardians in the $19^{\text {th }}$ century. Sovetskaya Etnografiya 2: 176-181. Original in Russian (Студенецкая, Е. Н. О большой семье у кабардинцев в XIX веке. Советская этнография 2: 176-181).

Studenetskaya, E. N. 1954. Everyday Life and Culture of the Kabardian People of the $18^{\text {th }}-19^{\text {th }}$ centuries. In Collection of Articles on the History of Kabarda. Iss. 3 (pp. 143-192). Nalchik: Kabardinskoe knizhnoe izdatel'stvo. Original in Russian (Студенецкая, Е. Н. Быт и культура кабардинского народа XVIII-XIX вв. Сборник статей по истории Кабарды. Вып. 3, с. 143-192. Нальчик: Каб. книжное изд-во).

The Legend of the Eshanokov brothers. 1891. Collection of Materials for the Description of Localities and Tribes of the Caucasus. Iss. 12. (pp. 27-36). Tiflis: Tipografiya kantselyarii Glavnonachal'stvuyushchego grazhdanskoi chast'yu na Kavkaze. Original in Russian (Сказание о братьях Ешаноковых. Сборник материалов для описания местностей и племен Кавказа. Выпуск 12, с. 27-36. Тифлис: Типография канцелярии Главноначальствующего гражданской частью на Кавказе).

Tornau, F. F. 1991. Caucasian Officer's Memories. Adygi. Kul'turno-istoricheskii zhurnal 2: 3-55. Original in Russian (Торнау, Ф. Ф. Воспоминания кавказского офицера. Адыги. Культурно-исторический журнал 2: 3-55).

Vasilyev, L. S. 1983. Early political and state structures. In Vasilyev, L. S. Problems of the Chinese state genesis. Moscow: Nauka. URL: http:/ abuss.narod.ru/Biblio/vasiliev.htm. Accessed May 2, 2019). Original in Russian (Васильев, Л. С. Ранние политико-государственные структуры. Проблемы генезиса китайского государства. М.: Наука. URL: http://abuss.narod.ru/Biblio/vasiliev.htm [дата обращения: 15.02.2018]).

Archives:

IHS KBSC RAS - Archive of the Institute of Humanitarian Studies of the Kabardino-Balkarian Scientific Center of the Russian Academy of Sciences.

OCSA AS KBR - Office of the Central state archive of Archival service of Kabardino-Balkar Republic. 